\title{
Relationship between Employer Branding and Corporate Social Responsibility
}

\author{
Jyoti Tomar $^{1}$, Dr Shivani Agarwal ${ }^{2}$, Dr. K. R. Chaturvedi ${ }^{3}$ \\ ${ }^{1}$ Research Scholar, Dr. A. P. J. Abdul Kalam Technical University, Lucknow, India \\ ${ }^{2}$ Assistant Professor, KIET School of Management, KIET Group of Institutions, Delhi-NCR, Ghaziabad, India \\ ${ }^{3}$ DR A. P. J. Abdul Kalam Technical University, Lucknow, India \\ 1jyotinehra30@gmail.com, ${ }^{2}$ jindal.shivani24@gmail.com, ${ }^{3} \mathrm{kr}$ _chaturvedi@rediffmail.com
}

\begin{abstract}
Employer branding defines an employer's reputation as a potential employer, an employee's value proposition, as opposed to a general brand name and value proposition for consumers. Employer branding is an effective tool for the purpose of creating competitive advantage. It facilitates the treatment of employees as internal clients and also presents the image of the organization as a desirable place to work. Thus, attract the most talented workforce. In recent times, corporate social responsibility (CSR) has developed into a vital part of business. Companies must integrate public obligations towards internal as well as external stakeholders in their operations. For any organization, human resource is the most important stakeholder group. Thus, employers should focus on improving the employer-employee relationship. This study is conducted to determine the how the social responsibility of the company supports the employer branding in companies and what CSR communication methods are used by the companies to improve employer attractiveness. The research process includes literary analysis and empirical research and is based on content analysis to find out relationship between social commitment and employer branding.
\end{abstract}

Index Terms-Employer Branding, Stakeholders, Employer Attractiveness, public obligations.

\section{INTRODUCTION}

$\mathrm{W}$ ITH the development of the global economy, there is a growing need for companies to acquire and retain excellent talent to fulfill their desire to grow. According to Manpower Group study "54 percent of companies reported skills shortages. Businesses in 36 of the 44 countries find it harder to attract more talented talent than in 2018" [1]. To compete in this new war of talent it's time for leaders to focus on strengthening of their organizations' employer brand. In 1996 Ambler and Barrow incorporated the term "employee symbol" into the field of HRM research. Employer branding refers to applying marketing techniques to the recruitment process and retaining employees [2]. They suggested that internal marketing of employer brand helps to build greater level of employee motivation and thus achieve enhanced customer satisfaction.

Just as a business name makes a commitment to its consumers about a product or service, an employer brand makes a commitment to its current and prospective employees about the experience and opportunities they will have in that organization. In theory all employers have a brand, but all of them do not successfully participate in efforts to brand themselves as employers. Employee branding is one of the many important factors that helps the company to have competitive edge against the competitors.

In modern times with a growing interest in sustainability and corporate responsibility companies incorporate these things into their operations and communication. Now, companies are considered as a part of communities where they operate. Each organization has a financial, environmental and social responsibility towards its stakeholders. The main stakeholders of the company are employees. Therefore, it is important that company should invest in human capital, which returns in gain in terms of employees, company and society collectively. When an organization considers its employees as an asset, it results in a constructive effect on employees' motivation, performance and loyalty. Motivated employees improve the performance of the entire company and lay a solid foundation for the type of employer.

Corporate social responsibility (CSR), related to people and social well-being, of any company should begin from within the organization and it should be communicated externally in same manner. CSR has a positive impact on employees' physical and emotional well-being. It also reflects how the company is considered as an employer by the outside people and potential employees. Thus we can deduce that a company can use CSR to improve employer brand value in both ways internal and external.

Prospective employees notice about the organizational values and culture and check if they are matching with their beliefs [3]. If they observe the features of the organization positively, they identify themselves with the company, so they are most likely to be associated with the company [4].

A positive CSR image can enhance jobseekers' interest because of the pride that is expected from being associated with a responsible organization, apparent value fit with the organization, and expectations about how the organization treats its employees [5]. The paper is trying to determine the extent to which social responsibility of the company supports the employer branding and what CSR 
communication methods can be used to improve employee attractiveness.

\section{LITERATURE REVIEW}

The term 'Employer Branding' was given by Simon Barrow and Tim Ambler in 1996 at London School of Business. They defined employer branding as: "Employer branding is the package of functional, economic and psychological benefits provided by employment and identified with the employing company" [1]. Another definition says, "Employer branding is the process of building an identifiable and unique employer identity" [4]. Definition given by Richard Mosley defines employer brand as a part of strategic human resource process and for its functioning there should be cooperation among different functions of the company: "Employer branding is an effective commercial bridge between HR, internal communications and marketing" [6]. The given definitions give a quintessence of employer branding. Different business leaders have also explained employment brand in their words. As per Melanie Lundberg, AVP, Talent Management and Corporate Communications, Combined Insurance, Chicago "An employer brand is the reputation a company has in the marketplace as a place to work. It is how a company is perceived by both current and future employees." In words of Liuka Lobarieva, Brand Manager, Sigma Software "Employer branding is how companies say we are different" [7].

With recent research in field of CSR, its needs and impacts various scholars have also included the CSR perspective to the employer branding. Research shows that a firm's socially responsible image influences stakeholder engagement positively [8]. CSR practices of the organization positively impact the employees and it can be seen as increase of identification, association and commitment towards the organisation, organizational citizenship behavior and meaningfulness of work [9]. CSR improves employee commitment and productivity. Thus, it has positive impact on organizational performance [10]. According to global organization for CSR, 'Business for Social Responsibility', including CSR in business operations offers several advantages in terms of improved investor appeal and enhanced brand positioning. It also increases employee attraction, retention and motivational levels [11]. This means that CSR has positive impacts on both company and individual. A strong social responsive brand emerges as a strong employer brand. Not only best HR policies and competitive compensation, concern for society and socially responsible behavior is also a budding component of employer brand [12]. While studying attitudes of millennial job seekers' towards CSR, Klimkiewicz \& Oltra found that millennial job seekers are engrossed by the CSR-based employer image [13]. The social responsible behavior and CSR initiatives of the companies improve the trustworthiness of the employer
[14]. Thus, it can be deduced that along with organization culture and best HRM policies.

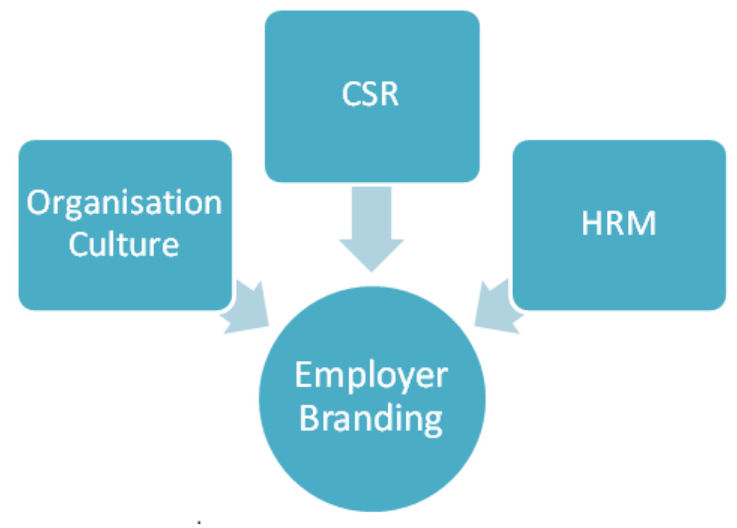

Fig. 1. Determinants of Employer Branding

\section{PROPOSED WORK}

In order to determine how CSR activities improve employer branding and how they affect the organization culture, an empirical case study of three Indian companies was carried out. The companies identified for the study are three Indian companies that are recognized among the best employers over a period of time, namely TATA Group, Infosys Ltd, and ITC Group [15]. These companies have huge employee base thus they largely depend upon skills of workforce and they also need to focus on employer brand value to make their employees motivated [16]. Content of websites of these companies was analyzed to study about the communication of CSR activities of the company. The content analysis was focused on content related to organization culture, values and employee engagement.

\section{Result AND Discussion}

\section{A. Observations}

Tata Group: The Tata Group is one of the oldest and biggest business groups of India. They are engaged in different CSR initiatives for a long time. They initiated labor welfare programs before it was endorsed by law. The values come from within the organization. The core value identified by the Tatas is 'Diversity and Inclusion'. The website mentions that the company is committed towards being an equal opportunity employer [19].

"At the Tata group, we encourage and nurture all forms of Diversity. We respect differences that are fundamental to an individual's identity such as age, gender, ethnicity, race, physical ability, mental ability, sexual orientation as well as latent and invisible differences that shape our perspectives like, education, work experience, parental status, etc. We are committed to being an equal opportunity employer, maintaining dignity and respect for all." 
Another factor identified is safety and health policy for employees. The Tata Group promises for providing a safe and healthy working environment for all employees and an injury and illness-free work place. As per company equitable safety and health protection measures will be provided to all employees. The company aims to be world leaders and to be considered as a benchmark in safety and health performance in their respective business sectors [18].

The Tata group carries out CSR activities in different areas such as Health, Education, Empowerment and Environment [20]. The group provides opportunities to current and retired employees to participate in voluntary activities for the community. Tata Volunteering Week (TVW) is celebrated every year in month of March and September. It brings together Tata employees, family members and retired Tata employees around the world to participate in different volunteering activities. ProEngage is a skillbased volunteering format designed to bring together nonprofit organizations and motivated professionals. It is developed to help non-profits build and sustain their capacity by utilizing volunteers' professional and personal skills and rich experience. Under ProEngage, Tata group provides volunteering projects in areas such as HR, finance, business planning, IT, web design, social media and marketing, mentoring and coaching to help non-profits build and maintain their capacity. Tata Group has launched Engage + . It is a platform where employees with the required professional skills and experience, can be awarded a full-time delegation for up to a period of 6 months, to lead and successfully complete an important non-profit project [17].

Such opportunities provide motivation and sense of recognition to the employees that they can make meaningful contributions to the community, in addition to just financial contributions. The Tata group has high employee motivation and employer brand, this is also identified in recent Harvard Study about 26/11 Mumbai Taj attack. None of the Taj employee left the hotel during the tragedy but stayed right through. They helped the guests to safely come out of the hotel and in process many employees lost their lives. Such commitment towards the workplace can only be achieved by having highly motivated staff and a strong employer brand [21].

Infosys: Infosys is one of the largest IT companies of India. Infosys is flag bearer of values and ethics in business. The company associates itself in the culture of inclusiveness and openness, and a mindset of exploration and applied innovation. The company provides ample opportunities to employees to upgrade their skills and get trained in different technologies [22]. The dedicated Education and Research (E\&R) department organize training of employees in different technologies and domains. These trainings help employees in achieving new challenges and taking up for future roles. Infosys values diversity and inclusion, and is committed to the principles of equal employment opportunity. Infosys has been an early adopter of a strong CSR agenda. Infosys has separate CSR arm, Infosys Foundation, to manage CSR programs. Sustainable development of communities where the company operates is an essential part of their CSR vision. Infosys CSR programs are focused in areas of education, healthcare, destitute care, and rural development, including building community empathy through employee volunteerism. Infosys aggressively support employee volunteering efforts [23]. The company provides different platforms to employees to work together and form volunteer groups. Different fields for voluntary activities provided to employee are Education, Health, Nutrition and Environment. Infoscions are provided with one year of paid sabbatical for up to one year to work for designated Indian NGOs on community projects [24]. SPARK program is designed for IT training and mentoring of government teachers and young students of rural areas. Infosys is in collaboration with more than 400 colleges to enhance the curriculum of technical education and making students industry ready. Infosys largely depends on solar power for its energy needs and usage of water recycling and rainwater harvesting is practiced in each campus [25]. Through these initiatives the employees feel attached to the society and this improves the association of employee with the organization.

\section{ITC Group}

ITC group put forwards its vision of 'Sab Sath Badhe' through its website. ITC projects itself as an organization that values integrity, creativity and passion [26]. Their focus is on continuous value addition to develop competencies. The company provides different training platforms for employees to improve their skill set. The company is proud to be Indian and provides wide range of world class products in Indian market. ITC's practices of sustainability and CSR are motivated by its vision to put the 'Nation First' [27]. ITC is one of the leading spenders on CSR in India. In year 2019 ITC is ranked as $7^{\text {th }}$ highest spender on CSR [28]. ITC continuously assess its contribution along three dimensions of the 'Triple Bottom Line' - economic, environment, and social. As a model contributor to the Triple Bottom Line, for five years in a row ITC has been 'Carbon Positive', for eight years in a row it is 'Water Positive' and for three years in a row it is 'Solid Waste Recycling Positive' [29]. ITC's CSR initiatives have created positive impact in 188 districts in 25 states/ union territories in India. ITC has a partnered with NITI Aayog to improve the agriculture and allied sector in selected 27 Aspirational Districts of 8 states [30]. The employees of ITC group value the CSR initiates take by company and value the change bought about in the society by their organization [31]. 


\section{B. Comparison between the companies}

All the three companies follow approaches for employer branding. The companies illustrate that the employees are a part of their CSR activities. The Tata group focuses on diversity, inclusivity and health and safety of the workforce. They have shown commitment towards work life balance and voluntarism in employees. Infosys has focused in strengthening employees' capabilities through training and innovation. It has also shown its interest in reducing carbon foot prints and working towards sustainability. The ITC group is keeping its ideas of ' $\mathrm{Na}$ tion First' in its functions and inculcates a sense of association with nation growth with the employees. All three has shown that their CSR activities are committed towards development of society where the company operates and working towards environment and sustainability. Tata Group and Infosys are focused on giving opportunities to employees for enhancing their skills and also putting their expertise to betterment of society through paid voluntary sabbatical. Tata Group and ITC Group both have diversified presence in different sectors; both have a large number of people that are impacted by their value chain. Thus, they have shown a huge commitment towards the communities where they operate. The companies are using their website as a means to put forward their CSR activities and voluntary work done by the employees, thus, showcasing them as better place to work.

\section{CONCLUSION AND Future WORK}

The study shows that the CSR activities of the company develop a sense of identification and association in company. The companies have identified importance of CSR in branding process and they have aligned the CSR functions along with HRM processes. Through employee voluntarism the companies motivates employees to work towards society along with their jobs. This gives job security as well as purpose of work to the employee. The employee friendly and social oriented culture of the organization strengthens the employee brand. For harvesting optimal branding benefits the internal functions and the CSR activities need to be communicated outside too. This can be achieved through websites, annual reports, short features etc.

Future studies can be carried out to find out various CSR initiatives that impact Employer branding in a positive manner. Also, there is scope of quantitative studies to ensure the impact of CSR initiatives of particular organization in terms of profit gained.

\section{REFERENCES}

[1] PTI. (2020, January 17). Global talent crunch hits record high, $54 \%$ companies globally face talent shortage. Retrieved August 23, 2020, from https://economictimes.indiatimes.com/jobs/globaltalent-crunch-hits-record-high-54-companies-globally-face-talentshortage/articleshow/73335727.cms
[2] Ambler, T., Barrow, S. (1996) The employer brand. The Journal of Brand Manaement, Volume 4(3), Page No.185-206. https://doi.org/10.1057/bm.1996.42

[3] Chatman, J. A. (1989). Improving Interactional Organizational Research: A Model of Person- Organization Fit. The Academy of Management Review, Volume 14(3), 333-349.

[4] Backhaus, K. and Tikoo, S. (2004), Conceptualizing and researching employer branding. Career Development International, Vol. 9 No. 5, Page No. 501-517. https://doi.org/10.1108/13620430410550754

[5] Jones, D. A., Willness, C. R., \& Madey, S. (2014). Why are job seekers attracted by corporate social performance? Experimental and field tests of three signal-based mechanisms. Academy of Management Journal, 57(2), Page No. 383-404. https://doi.org/10.5465/amj.2011.0848

[6] Mosley, R. (2014). Employer brand management: practical lessons from the world's leading employers. John Wiley \& Sons.

[7] What is Employer Branding? 26+ Business Leaders \& Branding Experts Share Their Own Definition. (2019, April 16). Retrieved September 2, 2020, from https://b2b.kununu.com/blog/what-isemployer-branding-definition-from-experts

[8] Greening DW, Turban DB. (2000) Corporate Social Performance As a Competitive Advantage in Attracting a Quality Workforce. Business \& Society, Volume 39(3), Page No. 254-280. doi:10.1177/000765030003900302

[9] Aguilera, R. V., Rupp, D. E., Williams, C. A., \& Ganapathi, J. (2007). Putting the S back in corporate social responsibility: A multilevel theory of social change in organizations. Academy of management review, 32(3), Page No. 836-863. https://doi.org/10.5465/amr.2007.25275678

[10] Ali, I., Rehman, K. U., Ali, S. I., Yousaf, J., \& Zia, M. (2010). Corporate social responsibility influences, employee commitment and organizational performance. African journal of Business management, 4(13), Page No. 2796-2801. https://doi.org/10.5897/AJBM.9000159

[11] Kotler, P., Hessekiel, D., \& Lee, N. (2012). Good Works!: Marketing and Corporate Initiatives that Build a Better World...and the Bottom Line, NJ: Wiley. ISBN: 978-1-118-20668-3

[12] Kashikar-Rao, M. (2014). Role of CSR in employer branding: Emerging paradigm. Review of HRM, 3, Page No.188.

[13] Klimkiewicz, K., \& Oltra, V. (2017). Does CSR enhance employer attractiveness? The role of millennial job seekers' attitudes. Corporate Social Responsibility and Environmental Management, 24(5), Page No. 449-463.

[14] Bustamante, S., \& Brenninger, K. (2013). CSR and its Potential Role in Employer Branding An Analysis of Preferences of German Graduates. In Making the number of options grow. Contributions to the corporate responsibility research conference.

[15] Peoplestrong. (2019, November 07). Best Companies to Work For Survey. Retrieved September 12, 2020, from https://www.peoplestrong.com/best-companies-to-work-forsurvey/

[16] India's top employers 2013: Branding makes a telling difference. (2014, August 05). Retrieved September 10, 2020, from https://www.businesstoday.in/magazine/cover-story/businesstoday-peoplestrong-best-companies-to-work-for-2013/story/ 208130.html

[17] Engage Plus. (n.d.). Retrieved September 3, 2020, from https://www.tataengage.com/AboutEngageplus.aspx

[18] Health. (n.d.). Retrieved September 10, 2020, from https://www.tata.com/community/health

[19] CSR. (n.d.). Retrieved September 10, 2020, from https://www.tatasustainability.com/CSR.aspx

[20] Environment. (n.d.). Retrieved September 10, 2020, from https://www.tata.com/community/environment

[21] Taj Hotel Attack: Harvard learns new lesson in Tata's recruitment style. (2020, September 08). Retrieved September 10, 2020, from https://indiainternationaltimes.com/taj-hotel-attack-harvard-learnsnew-lesson-in-tatas-recruitment-style/4506

[22] Infosys. (n.d.). Retrieved September 10, 2020, from http://www.infosys.org/

[23] Culture. (n.d.). Retrieved September 10, 2020, from https://www.infosys.com/careers/culture.html 
[24] Social. (n.d.). Retrieved September 10, 2020, from https://www.infosys.com/sustainability/social.html

[25] Makwana, K., Dave, G., (2014) Employer Branding: A Case of Infosys, International Journal of Humanities and Social Science Invention, Volume 3, Issue 6, Page No.42-49

[26] Sab Saath Badhein. (n.d.). Retrieved September 12, 2020, from https://www.itcportal.com/sab-saath-badhein/default.html

[27] Corporate Social Responsibility. (n.d.). Retrieved September 12, 2020, from https://www.itcportal.com/sustainability/corporatesocial-responsibility.aspx

[28] Impact Studies. (n.d.). Retrieved September 12, 2020, from https://www.itcportal.com/sustainability/impact-studies.aspx

[29] About ITC. (n.d.). Retrieved September 12, 2020, from https://www.itcportal.com/about-itc/index.aspx
[30] Fernandes, K. (2020). CSR of ITC. Retrieved September 13, 2020, from https://thecsrjournal.in/itc-csr-report-india/itc-csr/

[31] Gurrala, J. (2019). Employees' Perception Towards The Corporate Social Responsibility Initiatives and The Sustainability Practices of ITC Limited -An Empirical Analysis. International Journal of Human Resources Management (IJHRM), Vol. 8, Issue 2, Page No. $1-20$ 